\title{
'BUNKER' DEMOCRACY AND THE CHALLENGES OF SUSTAINING DEMOCRATIC VALUES IN NIGERIA An Appraisal of the 2011 General Elections
}

\section{Emmanuel O Ojo, PhD}

\author{
Emmanuel O Ojo is a current Reader in the Department of Political Science, \\ University of Ilorin, Kwara State, Nigeria \\ Email: eojo12000@yahoo.com
}

\begin{abstract}
This paper has two focal points. It undertakes a critical review of Nigeria's 2011 general elections vis-à-vis manifestations of violence across all the regions and zones of the country. It also attempts an in-depth and dispassionate overview of the nexus between democracy and violence. The paper infers that Nigeria is currently operating an 'insecurity-based democracy' which can literally be called a 'bunker democracy', allegorically describing Nigeria as a country where politicians and the electorate are in constant fear and trepidation for their lives when an election is imminent. I argue that this unwholesome situation should be addressed so that Nigeria does not suffer democratic regression and undue relapse to military autocracy and absolutism.
\end{abstract}

Keywords: absolutism, peace, violence, insecure democracy

\section{INTRODUCTION}

The following statement was made jointly by the global watchdog Human Rights Watch and the Nigeria Bar Association in 2011, urging the Federal Government to set up a special panel to investigate and prosecute election-related abuses and violence (The Nation 14 March 2011, p.4):

Nigeria has a history of violent and deeply flawed elections. At least 300 people were killed in violence linked to the last general elections 
in 2007 ... Since November 2010, more than 50 people have been killed in violence linked to political party primaries and election campaigns and the level of violence is expected to increase in the run-up to the April poll.

The above quotation epitomises the central argument of this article, the thrust of which is basically to lend credence to the fact that democracy comes at a high price in many countries. Each year, hundreds of people lose their lives in connection with fiercely contested elections (Hoglund 2009, p. 42). Concerns about security at election time have gained increased attention, especially in deeply divided societies such as Nigeria, Sudan, the Democratic Republic of Congo and Zimbabwe (Hoglund 2000, p. 2; Reilly 2002, pp. 156-170). In a perceptive work, Adekanye summed the problem up thus: 'elections in the country have often been characterized with political tension, crisis, assassination and high levels of violence' (Adekanye 1990, p. 2).

As Africa's largest democracy was preparing for the 2011 polls, serious questions remained about Nigeria's capacity and political will to conduct free, fair and peaceful elections. Since independence in 1960, 'violence and myriad irregularities have persistently marred the process of electing the country's leaders' (Onwudiwe \& Berwind-Dart 2010, p. 2). No doubt, fierce ambition among Nigerian politicians is certainly part of the problem. In addition, 'elections have been about power: controlling it, undermining it, and distributing it' (Samuel 2016). Other predisposing factors to electoral violence include monetisation of politics, poverty and unemployment, imposition of unpopular candidates and political thuggery.

In a democracy, an election campaign is supposed to be conducted as a peaceful and open discourse of persuasion. In Africa, however, elections more closely resemble bitter struggles over access to the resources controlled by the state, which are the biggest prize in most African states. Given these high stakes, politicians resort to a variety of means - fair or foul - to attain public office (Bratton 2008, p. 21). This is because persuasion alone seldom generates enough support; candidates regularly attempt to purchase or coerce votes (Bratton 2008, p. 21). Since the rebirth of Nigeria's democracy in 1999, violence of varying levels has been an unfortunate staple of Nigerian elections. The risk of election violence nationwide is unacceptably high (Onwudiwe \& Berwind-Dart 2010, p. 2). It was so bad that prior to the 2011 elections, merely declaring oneself an aspirant was enough to put one's life at great risk.

A number of factors are responsible for the high incidence of electoral violence in Nigeria. These include dissatisfaction with government performance, competition for resources, inter- and intra-group distrust, joblessness, and anger 
at an abundance of unscrupulous politicians with little respect for due process or the rule of law. In an earlier work (Ojo 2009a, pp. 1-218) I argued that much of the difficulty with electoral violence in Nigeria is not unconnected with the failure of mechanisms of national integration in Nigeria's deeply divided and plural society. The unprecedented spate of violence associated with the 2011 election has become a great challenge to sustainable democracy in Nigeria (Ojo 2009a, pp. 1-389).

This paper has two main foci. First, I critically review Nigeria's 2011 general elections vis-à-vis manifestations of violence, covering pre-election, election-day and post-election conflicts across all regions of the country. The second thrust has to do with the exploration of the nexus between violence and democracy, thereby bringing to the fore the concomitant impact of violence on democracy. To achieve this aim, the paper is organised into a number of sections. With brief introductory remarks, the paper begins with a conceptual framework divided into two parts. The allegory of 'bunker democracy' is explicated, after which I proceed to conceptualise electoral violence without necessarily being definitional. The third part of the paper is a survey of electoral violence in all zones and regions of the country, to empirically establish the tempo and intensity of electoral violence as visited on the polity. Section four explores the nexus between democracy and violence. The paper concludes with a suggestion that because of Nigeria's 'bunker democracy', state security apparatus might need to be strengthened so that the polity does not relapse into military dictatorship and absolutism.

\section{CONCEPTUALISING ‘BUNKER DEMOCRACY’ AND ELECTORAL VIOLENCE}

In military terminology, a 'bunker' is an 'underground shelter' (Fowler \& Fowler 1974, p. 158). In an unconventional application of the term for the purpose of this paper, it is used in relation to democracy ${ }^{1}$ - the very antithesis of the military ${ }^{2}$. In this application to democratic elections, Nigeria is currently operating an 'insecurity-based democracy' (Dukor 2011, p. 20). It is a system where the masses of the people and the electorate live in constant fear and trepidation, and scamper for safety, while the politicians - armed with mortars, bombs, grenades and rifles

1 In his study of the 2007 General Elections in Nigeria, Omotola (2009) described the process as 'Garrison' democracy much as the 2011 election is perceived here as 'Bunker' democracy.

2 For other sources where the term was deployed, see these relevant works: Emmanuel O. Ojo, 'The military and democratic transition in Nigeria: An in-depth analysis of Gen. Babangida's transition program (1985-1993)', in Journal of Politics and Military Sociology, vol. 28, no. 1 (Summer) 2000, pp. 1-20; Emmanuel O. Ojo, 'Taming the monster: Demilitarization and democratization in Nigeria', in Armed Forces and Society, vol. 31, no. 2 (January 2006), pp. 254-272; and Emmanuel O. Ojo, 'Guarding the "Guardians" - A prognosis of panacea for evolving stable civil-military relations in Nigeria', Armed Forces and Society, vol. 35, no. 4 (July 2009) pp. 688-708. 
in pursuit of naked and inordinate power - campaign from the trenches. In preelection Nigeria, attending a campaign rally was a big risk. During the elections, it was equally risky to venture close to polling points in an attempt to perform one's civic duty, as the empirical evidence cited in this paper shows. In the words of a Nigerian philosopher, 'in Nigeria's bunker democracy [...] is a harvest of freedom without human value, milk of liberty and equity' (Dukor 2011, p. 20). The idea of social and political freedom stems from the period before Nigeria's civil war. This freedom constantly sets the political landscape and the civil society aflame.

The reality, however, is that there cannot exist an ideal democratic government without security of life and property, where security is conceptualised as a social, bodily and mental state that guarantees protection of life and property (Dukor 2011, p. 20). Democracy, on one hand, means togetherness and recognition of the human person in running group affairs, while the rule of law is a body or assemblages of signs or conventions approved by the society for security, governance and development. From a philosophical point of view, security and democracy are not in contradiction; they are borne out of instrumental reason and applied to the human social nature. Their superstructure is, therefore, constituted by human nature and reason. On the other hand, the rule of law is a social structure superintending the observance of reason for the overall interest of human beings. Nonetheless, 'insecurity-based' democracy is a contradiction to the democratic canon, the rule of law and reason, a total negation of what the values of democracy stand for. Thus, it is the high level of insecurity I describe in this paper that has given the Nigerian version of democracy the epithet of a 'bunker democracy'.

\section{ELECTORAL VIOLENCE}

Electoral violence can be perceived as any form of election-related violence. In a research report, Adetula conceptualises it as 'any violence (harm) or threat of violence (harm) that is aimed at disrupting any part of the electoral or political process during the election period' (Adetula 2007, p. 227). This perception assumes that 'election violence generally involves political parties, their supporters, journalists, agents of government, election administrators and the general population which include threats, assault, murder, destruction of property, and physical or psychological harm' (Adetula 2007, p. 227). According to the International Foundation for Electoral Systems (IFES), electoral conflict and violence can be defined as 'any random or organized act or threat to intimidate, physically harm, blackmail, or abuse a political stakeholder in seeking to determine, delay, or to otherwise influence an electoral process' (Fischer 2002, p.3). 
By comparison, electoral security can be defined as the process of protecting electoral stakeholders, information, facilities and events.

Regarding the typology of electoral violence, Ebere Onwudiwe and Chloe Berwind-Dart are of the view that election conflicts typically fall into four related categories: intra-party feuding, inter-party clashes, electoral event violence, and communal unrest (Onwudiwe \& Berwind-Dart 2010, p. 5). In another relevant work, Nwolise (2007) defines the components and three dimensions of electoral violence as being physical, psychological, and structural forms of violence.

Going by the findings of the IFES in a survey, electoral conflict and violence can occur at five intervals in an election chronology, namely:

- Identity conflict can occur during the registration process, when refugees or other migrants from conflict regions are unable to establish or re-establish their officially recognised identities.

- Campaign conflict can occur as rivals seek to disrupt the opponents' campaigns, intimidate voters and candidates, and use threats and violence to influence participation in the voting.

- Balloting conflict can occur on election day, when rivalries are played out at the polling station.

- Results conflict can occur when there are disputes over election results and judicial mechanisms are unable to resolve such disputes in a fair, timely and transparent manner.

- Representation conflict can occur when elections are organised as 'zero-sum' events and 'losers' are left out of participation in governance (Fisher 2002, p. 3).

The same survey conducted in 2001 revealed four descriptive categories of conflict and violence that emerged. These categories suggest a variety of motives, victims and perpetrators (Fisher 2002, p. 4):

- voters in conflict with the state and claiming unfairness in the election process (Thailand, Zambia);

- the state in conflict with voters who challenge the election results or the electoral hegemony of the state (Chad, Belarus);

- political rivals in conflict with each other for political gain (Yemen, Benin, the Philippines, Uganda, Fiji, Seychelles, Pakistan, The Gambia, Bangladesh, Sri Lanka); and

- a blend of the above three categories.

In relation to the foregoing, the term 'electoral violence' has been used generically in two strands of research. In the first approach, electoral violence is seen as a 
subset of activities in a larger political conflict. In the second approach, electoral violence is seen as the ultimate kind of electoral fraud (Ojo 2011, pp. 1-16). Electoral fraud has been defined as 'clandestine efforts to shape election results' (Lehoucq 2003 , p. 233), and includes activities such as ballot rigging, vote buying, and disruptions of the registration process (Chaturvedi 2005). Both approaches focus on the goal-oriented or instrumental character of violence. Several instances cited in this paper are sufficient to buttress this point. I turn now to a survey of electoral violence across the various regions of Nigeria.

\section{A Survey of Electoral Violence}

This section of the paper examines the empirical indices of electoral violence across the six geopolitical zones comprising the 36 states of the Federal Republic of Nigeria. These are: North East - Adamawa, Bauchi, Borno, Taraba and Yobe; North West - Jigawa, Kano, Katsina, Kebbi and Sokoto; North Central - Benue, Kaduna, Kogi, Kwara, Niger and Plateau; South East - Abia, Anambra, Enugu and Imo; South West - Lagos, Ogun, Ondo, Osun and Oyo; and South South - Akwa Ibom, Cross River, Delta, Edo and Rivers (Ojo 201133). It is important to note that this survey is far from exhaustive of all cases of electoral violence, but includes as many cases as possible as reported by the mass media, both print and electronic, of conflict before the election, on election day and after the poll.

\section{North East Zone}

According to media reports, the North East presidential rally by Mallam Ibrahim Shekarau of the All Nigeria Peoples Party (ANPP) scheduled for Tuesday 29 March 2011 in Maiduguri was disrupted at mid-day. Gunshots were fired at a nearby filling station, causing pandemonium at Ramat Square, the venue of the event, leading to a stampede. By the end of the day four persons had lost their lives in the gun battle (Daily Sun 30 March 2011, pp. 1 \& 6).

In Maiduguri, the Borno State capital, the ANPP governorship candidate, Modu Fannami Gubio was murdered in broad daylight on Friday 28 January 2011, by gunmen who apparently trailed him by motorcycle from Maiduguri mosque, where he had gone to observe the Moslem Jumat prayers. Also killed were Governor Ali Modu Sheriff's brother, Alhaji Goni Modu Sheriff, a former chairman of Ngala Local Government Area, and four others including a 10-yearold boy. At the time, the ANPP was the ruling party in the state, and according

3 At a workshop, participants agreed that violence is antithetical to democracy and the conduct of free and fair elections. 
to media reports, the party was believed to have a strong chance of retaining the governorship in the April general elections (The Nation 31 Jan 2011, p. 1). A day before the presidential election, Maiduguri witnessed another sad event as two gunmen - suspected to be from the Boko Haram sect - laid siege to residents of Gwange suburb and killed two people; a further two soldiers and five civilians sustained gunshot injuries (Sunday Tribune 17 April 2011, p. 5).

On election day, Maiduguri was like a battlefield. Bombs exploded in two separate places in the city, killing two and leaving no fewer than 10 persons injured. Another bomb, which exploded at about $12 \mathrm{~h} 00$ - thirty minutes before completion of the accreditation of voters - left no fewer than ten wounded, with seven of the victims critically injured. A female police officer was injured and one of the presiding officers lost his eyes during the mid-day blast. Barely five hours later, another explosion occurred at Abaganaram collation centre where Independent National Electoral Commission (INEC) officials were collating election materials after the poll. The blast killed Ahmad Maira Abihud, an undergraduate at the University of Maiduguri, and four other persons were badly injured. The 37-yearold Abihud, who reportedly died on the spot, was an ad hoc staff member of the INEC.

By 20h00 on Saturday 29 March 2011, the streets of Maiduguri were deserted, as people warned their relatives and friends to remain indoors. Earlier, Nigerian Compass $_{L}$ a national daily, had reported that a violent clash between supporters of the People's Democratic Party (PDP) and the Action Congress of Nigeria (ACN) had left two people dead in Bauchi State. Twenty houses and five cars were torched in the clash, which occurred in Katanga Warji, headquarters of Warji Local Government Area in the North East. All affected buildings and vehicles belonged to chieftains of the two political parties (Nigerian Compass 30 March 2011, p. 1).

The post-poll conflict which broke out in the north spread to Adamawa State in the same zone when irate youths caused mayhem and destroyed property worth millions of naira. To restore peace to Adamawa State, Governor Murtala Nyako imposed a dusk-to-dawn curfew. No fewer than 50 youths were arrested (National Mirror 17 April 2011 p. 3; Vanguard 20 April 2011 pp. 1 \& 5). Post-poll violence also spread to Bauchi State, where six members of the National Youth Service Corps (NYSC) were killed in an orgy of violence that engulfed some states in the north following the announcement of Dr Goodluck Jonathan as the president-elect. Twenty people, including two policemen, were murdered in cold blood by rioters protesting the alleged rigging of the election (Nigeria Compass 20 April 2011, p. 1). The presidential election in Bauchi State was partially marred by violence as youths in Migan Local Government Area burnt down part of the INEC building and injured two voters (Sunday Punch 17 April 2011). 
Perhaps the most critical election-related violence in the zone occurred with the invasion of villages in Tafawa, Balewa and Bogno Local Government Areas in Bauchi State. Rioters attacked and invaded the villages in the two council areas and appeared to be after one thing: villagers' voters' cards. As they moved around attacking people in the area, they dispossessed their victims of their cards. The attackers were said to have repeated their invasion of the area after the National Assembly election was rescheduled, before it was eventually shifted to 9 April 2011. In the wake of both attacks, no fewer than 50 people - predominantly Christians - were feared killed, and about 100 buildings were allegedly set ablaze by the attackers.

The villages that were attacked included Imbira, Goshe, Goshkarbo, Namu, Mingil, Fada, SabonLaji, Gongo and Yola-Bogoro. According to one of the villagers, 'their intention was to make sure we did not vote in the election because their main target was our voters' cards, and they succeeded in burning so many of them. Now we can't vote in any of the elections' (The Nation 9 April 2011, pp. 1415; Nigeria Tribune 9 April 2011, p. 4). At the last count, 92 people had been killed in the North East zone of the country alone in connection with the 2011 elections.

\section{North West Zone}

The North West zone comprises five states. The zone did not witness much violence and turmoil either in the pre-election period or on election day. However, it did witness post-election violence as the fall-out of the presidential election. Severe violence erupted in most northern states, leading to loss of life and destruction of property. According to media reports, no fewer than 20 churches and houses belonging to members of the PDP and non-indigenous people were set alight (National Mirror 19 A pril 2011, pp. 1-3; 53). In Katsina State, angry youths burned down shops, worship centres and private houses in six local government areas in protest against the outcome of the presidential election. Several houses with PDP posters on their walls or gates were also attacked, as well as the party secretariat in the area (National Mirror 19 April 2011, pp. 1-3; 53).

Violence also broke out in Kano, the stronghold of General Muhammadu Buhari, as restive Muslim youths went on the rampage. As the results of the presidential poll trickled in, Christians and non-natives were also attacked in the confrontation. Notable politicians who were victims of the unprovoked attack included two former Speakers, Salisu Buhari, whose multimillion naira factory on Hadejia Road was vandalised, and Ghali Na'Abba. The number of deaths was unspecified (National Mirror 19 April 2001). In Sokoto, soldiers and mobile policemen were drafted to the streets following protests across the city and its environs. The protesting youths torched a house at Rijiya, and two vehicles and a 
motorcycle belonging to officials of Rima Radio, Sokoto were set alight. Similarly, five vehicles were destroyed at the radio station and several others were smashed across the city (National Mirror 19 April 2011).

In the build-up to the election, security operatives had envisaged the crisis. For instance, in Kano, men of the Nigerian Customs Service impounded more than 190 pairs of military uniforms and bulletproof vests at Mallam Aminu Kano International Airport (The Nation 7 April 2011, p. 2). Compared with the North East, the carnage was not as alarming.

\section{North Central Zone}

This zone, comprising six states, was not immune from electoral violence. Jos, Plateau State's capital, first witnessed a crisis when two people were killed and one wounded in skirmishes that occurred over the registration of voters at Tina Junction (Daily Sun 18 January 2011, p. 7). Suleja in Niger State was rocked on Thursday 18 January 2011 by two explosions at a PDP rally in the town, which killed at least 13 people and injured 20 others. Victims were severely injured, leaving some in a coma and others with lost limbs. According to media reports, some of the injured were members of the Federal Road Safety Corps, the Nigeria Security and Civil Defence Corps and other security outfits drafted to the venue of the rally. Niger State Governor Aliyu Babangida was whisked away from the scene by security agents (The Punch March 2011, p. 1).

In Benue State, unknown gunmen in the early hours of 18 March 2011 shot and killed Emmanuel Ajibo, an aide to the ACN senatorial candidate for Benue State, General Lawrence Onoja. Onoja blamed the killing on those who wanted to rule Idoma by hook or by crook. With preparations for the senatorial election in top gear, the Office of the Senate President, Senator David Mark, raised the alarm that his campaign train had been attacked by armed thugs under way to Igumale, the headquarters of Ado Local Government Area in Benue State (The Nation 19 March 2011).

As preparations for the rescheduled National Assembly election across the country were at fever pitch, a bomb blast rocked the office of the INEC. The dastardly act was timed to coincide with a meeting of the ad hoc staff of the commission, the majority of whom were former corps members checking their names and placements for the National Assembly elections scheduled for the next day. The explosion sent no fewer than 13 young men and women to an early grave, while more than 20 others were left with permanent physical disabilities. The explosion also pulled down the fence of the office, shattered virtually all the louvers of the windows in the complex, and destroyed the V-SAT of the office. 
(The Nation 16 April 2011, pp. 14-15). An eyewitness of the Suleja bomb blast recounted thus:

I saw some young men and women who were amputated by the bombs. Some of them were rendered immobile. Many of them were glued to a spot in pains, while many others were soaked in blood and unable to move. The injured people were just there. It was a horrible sight. I could not stand the sight of blood, so I left.

(Daily Sun, 11 April 2011, p. 16)

This orgy of violence was unprecedented in the annals of electioneering in Nigeria. With the outcome of the presidential election not in favour of any of the northern candidates, the North Central zone was engulfed in unprecedented violence. For instance, in Kaduna, Kaduna State, the house of Vice-President Namadi Sambo was burned down by irate protesters. Churches and mosques were also torched. Scores of dead bodies were recorded. The protesting youths forced open Zaria Central Prison and freed the inmates. The INEC office was set alight and areas such as Trikania, Malabalindo, Sabin Tasha, Naragi, Ungwan Sarkin and Kawo were also affected. To avert an escalation of the crisis, the Kaduna State Government immediately imposed a 24-hour curfew on the metropolis and its environs, urging all security agencies immediately to enforce the order.

The post-election violence spread to Niger State where aggrieved youths in Minna, the state capital, took to the streets following the release of the presidential election results. At Sabon Gari, mostly dominated by the Igbo, the hand of a female civil defence officer was cut off and three cars were set on fire. Scores of cars with PDP stickers as well as five churches were set ablaze at Maitunbi, Shango, Angwan Kaje and other areas of the town. Niger State declared three days of curfew in the five major towns of Minna, Suleja, Kontagora, New Bussa and Bida to contain the spread of the violence in the state.

The North Central zone was the worst hit by electoral violence. The official figures released by the Inspector General of Police Hafiz Ringim were not only shocking but did great damage to the credibility of the 2011 general elections. According to Ringim, 520 persons were killed in post-election violence in Kaduna and Niger States alone. He said that Kaduna State accounted for 518 deaths (of whom six victims were policemen) and the remaining two persons were killed in Niger State. The Inspector General of Police also noted that 77 persons were injured in Kaduna State, and 22000 persons were displaced as a result of the crisis in the state. He reported that destruction of property had been colossal, with 157 churches, 46 mosques, 1435 houses, 437 vehicles and 219 motorcycles set on fire 
(The Punch, 2 June 2011, p. 6). ${ }^{4}$ At the last count, no fewer than 556 persons had died, with scores wounded in that zone.

\section{South East Zone}

This zone comprises four states. Surprisingly, despite the high rate of youth restiveness prior to the election, the zone was relatively calm. But in Ebonyi State alone, about six persons were killed in Amuda Ezza North Local Government Area during an orgy of violence that also left many with various degrees of injuries (National Life 26 April 2011). During the voters' registration exercise in the Ndike Amugu Ikino community in Ebonyi State, three persons were allegedly shot and one person went missing in a gun duel between rival groups over who should take charge of the Direct Data Capture machines for voter registration (Daily Sun 20 January 2011, p. 6).

Shortly before the postponement of the National Assembly election was announced, one person was confirmed dead in Ebonyi State as supporters of the People's Democratic Party and All Nigeria Peoples Party clashed. Still, the zone recorded perhaps the lowest rate of casualties.

\section{South South Zone}

This zone has five states. In Rivers State, an aspirant to the State House of Assembly, Mr Jacob Peter, was attacked by thugs suspected to be from his Degema Constituency. He was attacked while returning from Zambia to Port Harcourt, the venue of a proposed ad hoc delegates' election in Degema Constituency. It was rumoured that the attack occurred because he wanted to confront a PDP chieftain (The Nation 30 December 2010, p. 5).

In Akwa Ibom State, electioneering included a long convoy of vehicles, with youths singing and drumming as the crowd of residents waved excitedly. Suddenly, shots rang out and the carnival ended abruptly, and everyone ran for dear life. When the dust had settled, many ACN supporters of Akwa Ibom State governorship candidate, Senator John Udoedehe lay dead and property worth billions of naira had been destroyed (The Nation 15 March 2011, pp. 1-2). By the time Akwa Ibom began counting the loss of the ethno-political war that engulfed the state on Tuesday 14 March 2011, when PDP and ACN supporters clashed in Ikot Ekpene with a spillover in Uyo, collateral losses on both sides included 20 deaths, and 1300 brand new cars and tricycles destroyed. Also torched was

4 A number of other national dailies reported similar events: The Nation, Lagos, 16 April, 2011, p. 15; The Nation, Lagos, 9 April, 2011, p. 2; Nigerian Tribune, Ibadan, 9 April, 2011, p. 1. 
President Goodluck Jonathan and Governor Akpabio's campaign building. Four PDP supporters reportedly lost their genitals and 65 ACN supporters were in police custody.

In the words of Governor Godswill Akpabio,

This is no longer politics. You cannot just go and destroy over 800 brandnew cars and burn down over 500 brandnew "keke napep" [tricycles], and burn down all sorts of edifices in the place. They went as far as cutting the private parts - genitals of PDP members and they are in the general hospitals.

(Daily Sun 24 March 2011, p. 6; Nigeria Compass 10 April 2011, p. 5.)

Four persons were feared killed in election violence in Ogume Ndokwa West and Ughelli North Local Government Area of Delta State. Two were reportedly shot dead at Ogume by anti-riot policemen, who purportedly fired shots to quell an uprising; the other two were said to have been killed at Ughelli by suspected mercenaries. At the last count, electoral violence in the South South Zone had recorded 24 deaths (Daily Sun 24 March 2011, p. 6).

\section{South West Zone}

This zone, reputed to be the 'Wild West', comprises five states. This zone too was not immune from violence. During the election campaign, the Ondo State Police command summoned the leadership of the Action Congress of Nigeria (ACN) and the ruling Labour Party (LP) to an emergency meeting over the violent clash that occurred in Imeri in Ose Local Government Area. No fewer than 10 people had sustained injuries in the clash that forced residents of Imeri to scamper for safety (Saturday Punch 19 March 2011, p. 7). One person was reportedly shot dead after being hit by a stray bullet from yet-to-be identified hoodlums sponsored by one of the political parties (Saturday Punch 19 March 2011, p. 7).

In Ekiti State, in the Kota area of Omuo-Ekiti, two people were shot dead on Wednesday 23 March 2011 by men in police uniform, when supporters of the ACN and their PDP counterparts clashed. The body of one of the victims, the late Faluyi Kehinde Ayoola, was dumped by members of the PDP at the entrance of Governor Kayode Fayemi's office in Ado Ekiti (Daily Sun 24 March 2011, p. 12). In the neighbouring Osun State, the police recovered a large cache of arms in Atakumosa Local Government Area from a PDP member of the House of Assembly of Osun State, including 19 Italian pump-action rifles and 14 live cartridges, as well as expended ammunition and a long cutlass (The Nation 7 April 2011, pp. 1-2). 
Ibadan, the capital of Oyo State, lived up to its 'Wild West' reputation as guns boomed, blood flowed and bodies fell during the PDP local government congress. The major casualty of the 'war' was the Oyo State factional leader of the National Union of Road Transport Workers, Alhaji Lateef Salako (Eleweomo), who was allegedly killed in crossfire between his loyalists and suspected thugs (Nigeria Compass, 31 December 2010, pp. 1 \& 50). The Senate Leader, Senator Teslim Folarin, was said to have been at the scene of the fracas. He admitted that 'even my convoy was seriously attacked on my way home, and this resulted in the death of two of my supporters, while I also learnt that two others had their arms chopped off' (Nigerian Compass 31 December 2010, pp. 1 \& 50).

At Iseyin in Oyo State, PDP Secretary, Alhaji Bashir Akanbi claimed that Congress for Progressive Change (CPC) members clashed with his party members who were returning from a political tour of Oke Ogun Local areas. He also alleged that a chieftain of the CPC shot at the vehicle in which he was travelling. He said further that 'they broke the windscreen and all the glasses of the car and also looted my bag containing N250 000.00, a gold wristwatch, a silver wristwatch, all my chequebooks and ATM cards, as well as two dresses.' The attack claimed a life (Sunday Tribune 27 February 2011, p. 11).

In the neighbouring Ekiti State, the PDP Secretary in Ido-Osi Local Government Area, Toyin Akinlade, was killed by unknown gunmen in the early hours of Thursday 24 March 2011. The late Akinlade, who was a former councillor, met an untimely death in his home at midnight (National Life 25 March 2011, p. 35).

In Ogun State, no fewer than three people were reportedly killed at the Labour Party (LP) campaign rally in Ikenne Local Government Area, prompting the PDP to postpone its rally in the area (National Life 25 March 2011, p. 35). Around the same time, at least five vehicles were burnt when supporters of the PDP and the Accord Party clashed at Iwo Road, in Ibadan, Oyo State on Sunday 13 March 2011 (Sunday Tribune, Ibadan, 13 March 2011, p. 12). Segun Osoba, a former governor of Ogun State - who is also a chieftain of the ACN - disclosed that a member of the party was killed during last Saturday 13 March 2011 National Assembly election at Saje. Tajudeen Balogun, an ACN agent, who monitored the election at the Kessi-Emere unit at Saje, was on his way from the collation centre at the Saint Mary Primary School when he was shot by unknown assailants (Daily Sun 11 April 2011, p. 5). Earlier, the police had announced that one life was lost during the PDP ward congress in Ogun State. Many were also injured. The deceased was simply identified as one Toyin who was 27 years old (The Nation 30 December 2010, p. 5).

Osun State was not spared the venom of electoral violence. Tension was palpable in Ife town, as five supporters of an aspirant politician were killed in the early hours of Saturday 30 December 2010. The slain were said to have 
been supporters of an ACN House of Representatives candidate in Ife Federal Constituency, Mr. Rotimi Makinde. The victims were alleged to have been killed by persons sponsored by a politician in the town when he unleashed terror on Makinde's house and the candidate for the Senate, Hon. Jide Omoworare. A guard at Makinde's house and four members of a church in the neighbourhood were shot and killed.

Perhaps the worst case of electoral violence took place in Ibadan, the capital of Oyo State, where the National Union of Road Transport Workers became politicised and was caught between manipulation by both the ruling PDP and the opposition ACN. Prior to and after the gubernatorial election, the state capital was reeling from violence. The violence assumed a dangerous dimension in May shortly after the inauguration of the new governor, Senator Abiola Ajimobi, when several innocent lives were lost. The reason was that the loss of the ruling party in the state translated to the loss of the ruling elite in the drivers' union too. Oyo State Government had to set up a judicial panel of enquiry and also proscribed the union before peace could be restored to the ancient city. At a well-attended press conference, a faction of the proscribed union led by Alhaji Lateef Akinsola (a.k.a. Tokyo), disclosed that the leadership crisis rocking the union in the state had thus far claimed more than 200 innocent lives. In a 120-page memorandum submitted to the probe panel, the factional secretary of the union, Alhaji Lekan Aleshinloye, said the killings and destruction of property associated with the violence were not merely owing to intra-union conflict (Nigerian Compass 10 April 2011, p. 11). He averred that the other faction of the union was 'backed, empowered and bankrolled' by the ruling party governor of the state (Nigeria Compass 10 April 2011, p. 5).

From the above survey of all six geopolitical zones of Nigeria, it is clear that conducting the 2011 general elections was in many respects like a war. Holding elections is no doubt one of the vital aspects of democracy, and that several communities should have experienced it as such a dreadful event places a question mark over the credibility of the exercise. The question that the next segment of this paper attempts to answer is: How compatible are violence and democracy? And what intensity of violence can a polity absorb for an election still to be credible?

\section{Democracy and Violence: An Exploration of the Nexus}

Undoubtedly, democracy and violence are far from compatible. The former is a benign anarchy of diversity (Ake 1995). Democracy presupposes human sociability. It enjoins participation - a means of consensus-building. As averred by Nwolise, 'there can be no democratic election, democratization, consolidation of democracy, growth in democratic culture or internalization of best democratic practice in any country if electoral violence is prevalent' (Nwolise 2007, p. 155). 
Perhaps the greatest damage violence does to an election is to the credibility of the results (Ajulu 2008, pp. 33-51) and the accompanying succession crisis (Ojo 2007, pp. 24-32).

It is against this background that pre-election, election day and postelection violence have become a worrisome trend to scholars, politicians, the international community and public policy-makers in Nigeria alike. For instance, the International Society for Social Justice and Human Rights, in its 2011 report, disclosed that as a result of post-election violence linked to the 2011 general elections, the number of internally displaced persons in Nigeria had reached 6.3 million. The group explained that its last check showed that the number had increased from 5.6 million to the current intimidating figure owing to the post-election riots in some parts of the country. The Chancellor of the group, Chief Jackson Omeuazu, warned that the number of those dislodged from their communities could increase if proactive measures were not taken to check the trend (The Punch 25 April 2011, p. 6).

As a result of electoral violence prevalent in some northern states, the INEC had to postpone the 26 April 2011 governorship and state House of Assembly elections in Bauchi and Kaduna States. They cited the terrible security situation in the two states following the violence that erupted in some parts of the country over the previous presidential poll (Nigeria Tribune 22 April 2011, p. 4):

The magnitude, tempo and dimension of the violence which accompanied presidential poll result compelled the President - Dr. Goodluck Jonathan - of Nigeria to address the nation on why the country must be united:

... they killed and maimed innocent citizens. They set ablaze business premises, private homes and even places of worship. In some cases, they showed utter disrespect to all forms of authority, including our most revered traditional institutions. They systematically targeted population groups. They singled out and harrassed nationalistic politicians. They intimidated travellers.

The Nation 21 April 2011, p. 9

He went further to state in the same speech that:

If anything at all, these acts of mayhem are sad reminders of the events which plunged our country into thirty months of an unfortunate civil war. As a nation, we are yet to come to terms with the level of 
human suffering, destruction and displacement, including that of children to far-away countries, occasioned by those dark days.

The Nation 21 April 2011, p. 1

On the same issue, national daily The Guardian noted that:

The violence that broke out in some states following the announcement of the presidential election results is unfortunate and condemnable. It is a sad signal that rather than improve in their attitude over elections, politicians are still desperate, their supporters even more so. It is particularly worrisome that the violence occurred at a time all Nigerians should be congratulating themselves for successfully holding a presidential election that can go down in history as an orderly and peaceful one. Last Saturday's presidential election may not be the best Nigeria has ever had, it is certainly commendable when compared with similar elections in 1999, 2003 and 2007.

(The Guardian, Lagos, 21 April 2011, p. 14)

Be that as it may, vote rigging - which means accumulating votes through the use of violence - has devalued the vote, leading to apathy among the electorate and dampening their enthusiasm for democracy. This is because rigging, violence and intimidation made a mockery of the electoral process. In Africa, Asia and several other developing regions, thuggery and intimidation are the most popular methods used by political parties and politicians to exclude large proportions of the population (Ubi 2007, p. 21).

Writing on the consequences of electoral violence, Kristine Hoglund averred that it can have several negative effects. Violence and insecurity may cause low voter turnout, it can interfere with the registration of voters, or it may affect the validation of election results. In essence, it can influence both the electoral process and the outcome of elections. She added that violence during the election campaign targeting politicians can force candidates to resign their candidature (Hoglund 2009, p. 417). Corroborating this position, Michael Bratton in a perceptive work observed that 'in reality, people who are paid or threatened during the election campaign are actually less likely to turn out to vote on polling day. Threats of violence lead to an especially sharp reduction in voter turnout' (Bratton 2008, p. 622).

It is however imperative to note that violence is not in any way synonymous with the political culture of Nigerians. In a survey, a clear majority of Nigerians interviewed said that political violence was always wrong. Almost four out of five adult Nigerians (79\%) see political violence as 'never justified', even 'in support 
of a just cause'. The survey revealed that only $5 \%$ of Nigerians strongly support the 'necessity' of using violence in pursuit of political goals (Bratton 2008, p. 623). ${ }^{5}$ As revealed by the survey of the six geopolitical zones, the negative consequences of political intimidation include, in approximately equal proportions, threats to personal safety, threats to the safety of family members, and the loss of property (Bratton 2008, p. 624).

At the base of electoral violence are protests and agitations over socioeconomic issues, especially in ethnically defined constituencies (Despres 1975, pp. 131-157). From another perspective, electoral violence is a consequence of the weak capacity of new states and the difficulty they experience in enforcing laws (Adebayo \& Ojo 2009, p. 7).

\section{CONCLUSION AND RECOMMENDATIONS}

From the foregoing, and coupled with ethno-religious conflicts that have bedevilled Nigeria's political landscape as a regular worrisome phenomenon in the country, Nigeria presents a glaring picture of a beleaguered state (Ojo 2006, pp. 368-378). These and other development indicators are so dismal that the 2010 Global Peace Index report ranked Nigeria $137^{\text {th }}$ out of 149 countries surveyed (Global Peace Index 2010). The problem is that election administration and conduct have become a curse rather than a blessing, in view of the violence that accompany elections (Motsamai 2010).

In essence, one of the major challenges Nigeria's nascent democracy faces is conducting violence-free elections in which both the candidates and the electorate can participate without fear of being attacked or injured. In curbing electoral violence in Nigeria, two institutions readily come to mind: the judiciary and the mass media. No doubt, the judiciary is a crucial institution in established democracies of the world. This is not unconnected with the fact that constitutional government must in part be judicial government (Onyeoziri 2005, p. 3). The judiciary is assumed to be the guardian of the rule of law and the upholder of justice, fair play and equity. This is the reason that in Nigerian constitutions the judiciary enjoys the greatest measure of independence from both executive and legislative arms of government - except during military interregnum (Adebayo \& Ojo 2009, p. 17).

Despite the constitutional provisions that ordinarily prevail, the judicial organ is faced with two major problems, which to a large extent have encumbered its

5 For a detailed account of the forces between two factions of the PDP at the Local Government Congress of Ona-Ara Local Government Area, Ibadan, Oyo State, see Nigeria Compass, Isheri, December 312010. pp. 1 \& 50. It was in this confusion and violence that 'Eleweomo', a factional leader of National Union of Road Transport Workers (NURTW) in Oyo State was killed in cold blood. 
performance and exacerbated electoral violence. First, Nigerian judges are in most cases unable to interpret the laws to accord with the progressive aspirations of the people. Thus when elections are rigged, the perception of the majority of the electorate, including candidates in elections, is that justice might not be served by election petition tribunals. This perception has been responsible for some people resorting to lawlessness and violence (Ojo 2011, pp. 125-136). Secondly, certain judges are said to belong to secret local societies that are very powerful and feared by their members for imposing serious sanctions on them. Judges who belong to such secret societies are believed to have a double loyalty - that is, loyalty to the state and its laws, and loyalty to the secret societies and their obnoxious norms and dastardly acts.

Furthermore, there are widespread allegations of corruption against members of both the Bench and the Bar (Davies 1990, pp. 125-136). It is only transparency and accountability that can boost the confidence of the masses with regard to the judiciary. The judiciary is yet to pass that litmus test in Nigeria. The concomitant effect of lapses in justice has been exacerbating electoral fraud and violence.

In the final analysis, the role of the mass media in curbing electoral violence and promoting a sustainable democracy cannot be overemphasised (Ojo 2003, p. 5). With those two institutions (the judiciary and the mass media) taken care of, politicians too need to eschew a winner-takes-all kind of politics. In Africa, the state is central to the economic wellbeing of the citizenry; hence, politics of exclusion is antithetical to peace and tranquillity. Unless there is a sudden turnaround - and so far, there are few signs of it - the polity appears closer to the brink than ever before.

In its 2011 Failed States Index, the United States-based Fund for Peace rated Nigeria in $14^{\text {th }}$ position out of 177 countries analysed, the same spot it held in 2010. The country was only ahead of the world's 13 most miserable countries: Somalia, Sudan, Chad, Congo (DR), Haiti, Zimbabwe, Afghanistan, the Central African Republic, Iraq, Côte d'Ivoire, Guinea, Pakistan and Yemen. Using indicators such as security, state legitimacy, and factionalism and group grievances, Nigeria appeared to the Fund for Peace researchers to be close to the 2005 prediction by the US Central Intelligence Agency that the country could break up by 2015. The 2011 ranking of the country as the $14^{\text {th }}$ 'most failed' state in the world therefore underscores the precarious national condition as well as the imperative of taking immediate measures to arrest the downward slide (The Punch 30 June 2011, p. 18). 
Adebayo, PF \& Ojo, EO, 2009, 'Can Nigeria's nascent democracy survive', Journal of Sustainable Development in Africa, vol. II, no. 1, p. 7.

Adekanye, JB 1990, 'Election in Nigeria: problems and strategies', Journal of Electoral and Political Behaviour (Nigeria), vol. 1, no. 1, p. 2.

Adetula, VAO 2007, 'Election related violence in Nigeria - survey of trends and patterns in 2007 election', Politics and Society: A Journal of the Nigerian Political Science Association, issue 8, December, p. 227.

Ajulu, R 2008, 'Kenya's 2007 election: derailing democracy through ethno-regional violence', Journal of African Elections, special issue: Kenya, vol. 7, p. 33-51.

Ake, C 1995, 'A Plausible Transition', Tell 39, 25 September 1995, p. 35.

Bratton, M 2008, 'Vote buying and violence in Nigeria election campaigns', Electoral Studies, vol. 27, issue 4, pp. 621- 632.

Chaturvedi, A 2005, 'Rigging elections with violence', Public Choice, vol. 125, p. 25.

Davies, AE 1990, 'The independence of the judiciary in Nigeria: problems and prospects', African Study Monographs, vol. 10, no. 3, pp. 125-136.

Despres, LA (ed), 1975, Ethnicity and resource competition in plural societies, Mouton \& Co, The Hague, pp. 131-157.

Dukor, M 2011, 'Bunker democracy and governance in Nigeria', Daily Sun, February 8, p. 20

Fischer, J 2002, 'Electoral conflicts and violence: a strategy for study and prevention', IFES White Paper, February 5, p.3.

Fowler, HW \& Fowler, FG (eds) 1974, The Concise Oxford dictionary of current English, Oxford University Press Oxford, UK.

Global Peace Index 2010, Institute for Economics \& Peace, accessed from http: / / peacealliance.org/cms/assets / uploads/2013/05/2010-GPI-Results-Report. pdf

Hoglund, K 2000, 'Electoral violence in war-ravaged societies: the case of Sri Lanka', paper prepared for the Workshop on Power-sharing and Democratic Governance in Divided Societies, Center for the Study of War, PRIO, August 21-26, p. 2.

Hoglund, K 2009, 'Electoral violence in conflict-ridden societies: concepts, causes and consequences', Terrorism and Political Violence. vol. 21, p. 412.

Lehoucq, F 2003, 'Electoral fraud: causes, types, and consequences', Annual Review of Political Science, vol. 125, p. 25.

Maduabudi, D 2011, 'Bunker democracy and governance in Nigeria', Daily Sun, Lagos, 8 February, p. 20.

Motsamai, D 2010, 'When elections became a curse: redressing electoral violence in Africa', EISA, Policy Brief Series, no. 1, March.

Nwolise, OBC 2007, 'Electoral violence and Nigeria's 2007 election', in Ojo, EO (ed), 
Journal of African Elections, Special Issue, Nigeria 2007 General Elections, vol. 6, no. 2, p. 155.

Ojo, EO 2006, 'A survey of ethno religious crisis in Nigeria and its implications for democracy' in Ojo, EO (ed), Challenges of sustainable democracy in Nigeria, Ibadan, Nigeria.

Ojo, EO 2007, 'Nigeria's 2007 general elections and the succession crisis implications for the nascent democracy', Journal of African Elections, Special Issue, Nigeria's 2007 General Elections, vol. 6, October, pp. 24-32.

Ojo, EO 2009a, Challenge of sustainable democracy in Nigeria, Ibadan, Nigeria.

Ojo, EO 2009b, Mechanisms of national integration in a multi-ethnic federal state: the Nigerian experience, Ibadan, Nigeria.

Ojo, EO 2011, 'Electoral fraud in Nigeria: issues and dimensions', public lecture presented to Justice Mustapha Akanbi Foundation, an organised sensitisation workshop for civil society organisation in preparation for 2011 general elections, Ilorin, Kwara State, March 16-17 2011, pp. 1-16.

Omotola, JS 2009, ' "Garrison” democracy in Nigeria: the 2007 general election and the prospects of democratic consolidation, Commonwealth and Comparative Politics, Vol. 47, No. 2, pp. 194-220.

Onwudiwe, E \& Berwind-Dart, C 2010, 'Breaking the cycle of electoral violence in Nigeria', United States Institute of Peace, special report 263, p. 2.

Onyeoziri, F 2005, 'Federalism and state capacity in Nigeria', Ibadan, Journal of Social Science, vol. 3, September, p. 3.

Reilly, B 2002, 'Electoral systems for divided societies' Journal of Democracy, Vol. 13, No. 2, April 2002, pp. 156-170.

Samuel, ST 2016, 'Political thuggery and election in Nigeria and the law', accessed 24 March 2016. Available at:

http: / / www.nials-nigeria.org/journals/Shankyula\%20Tersoo\%20Samuel.pdf

Ubi, E 2007, 'The role of political parties in the 2007 general elections in Nigeria',

Studies in Politics and Society, issue 8, December, p. 21.

\section{Newspapers and magazines referenced in this paper}

Daily Sun, Lagos, Nigeria.

National Life, Lagos, Nigeria.

National Mirror, Lagos, Nigeria.

Nigeria Compass, Isheri, Nigeria.

Nigerian Tribune, Ibadan, Nigeria.

The Nation, Lagos, Nigeria.

The Punch, Lagos, Nigeria.

Sunday Tribune, Ibadan.

Vanguard, Lagos.

The Guardian, Lagos, Nigeria. 